Marquette University

e-Publications@Marquette

Psychology Faculty Research and Publications

Psychology, Department of

$7-1-2005$

\title{
The Effects of Non-Contingent Extrinsic and Intrinsic Rewards on Memory Consolidation
}

Kristy A. Nielson

Marquette University, kristy.nielson@marquette.edu

Ted Bryant

Medical College of Wisconsin

NOTICE: this is the author's version of a work that was accepted for publication in Neurobiology of Learning and Memory. Changes resulting from the publishing process, such as peer review, editing, corrections, structural formatting, and other quality control mechanisms may not be reflected in this document. Changes may have been made to this work since it was submitted for publication. A definitive version was subsequently published in Neurobiology of Learning and Memory, Vol. 84, No. 1 (July 2005): 42-48. DOI. (C) 2005 Elsevier. Used with permission. 
NOT THE PUBLISHED VERSION; this is the author's final, peer-reviewed manuscript. The published version may be accessed by following the link in the citation at the bottom of the page.

\title{
The effects of non-contingent extrinsic and intrinsic rewards on memory consolidation
}

\author{
Kristy A. Nielson \\ Department of Psychology and the Integrative Neuroscience \\ Research Center, Marquette University \\ Foley Center for Aging and Development, Department of \\ Psychiatry and Behavioral Medicine, Medical College of Wisconsin \\ Ted Bryant \\ Department of Psychology and the Integrative Neuroscience \\ Research Center, Marquette University
}

\begin{abstract}
Emotional and arousing treatments given shortly after learning enhance delayed memory retrieval in animal and human studies. Positive affect and reward induced prior to a variety of cognitive tasks enhance performance, but their ability to affect memory consolidation has not been investigated before. Therefore, we investigated the effects of a small, non-contingent, intrinsic or extrinsic reward on delayed memory retrieval. Participants $(n=108)$ studied and recalled a list of 30 affectively neutral, imageable nouns. Experimental groups were then given either an intrinsic reward (e.g., praise) or an extrinsic reward (e.g., \$1). After a one-week delay, participants' retrieval performance for the word list was significantly better in the extrinsic reward groups,
\end{abstract}

[Neurobiology of Learning and Memory, Vol 84, No. 1 (July 2005): pg. 42-48. DOI. This article is (C) Elsevier and permission has been granted for this version to appear in e-Publications@Marquette. Elsevier does not grant permission for this article to be further copied/distributed or hosted elsewhere without the express permission from Elsevier.] 
whether the reward was expected or not, than in controls. Those who received the intrinsic reward performed somewhat better than controls, but the difference was not significant. Thus, at least some forms of arousal and reward, even when semantically unrelated to the learned material, can effectively modulate memory consolidation. These types of treatments might be useful for the development of new memory intervention strategies.

Keywords: Memory consolidation, Reward, Positive affect, Long-term memory, Emotion, Memory modulation, Arousal

\section{I ntroduction}

Each day people experience, learn, and recall events while in some affective or emotional state. Under these conditions, some occurrences are remembered better than others. Thus, it seems reasonable to believe that there should exist mechanisms to differentiate the events that are more important than others such that the important experiences are then remembered better than those of lesser importance. Studies suggest that one such mechanism is emotional or arousing content; events that are emotional or arousing are often better remembered than those lacking in such content (McGaugh, 2000). The selection process for permanent storage in memory is believed to occur after the initial moment of learning (Squire, 1987), during the stages of memory storage that occur over time (cf. Deutsch \& Deutsch, 1966; McGaugh \& Gold, 1989; Müller \& Pilzecker, 1900). Evidence shows that modulation in the memory storage process can occur after the original experience (cf. Gold \& van Buskirk, 1975; McGaugh, 1966; Squire, 1986), enhancing long-term but not immediate retrieval (e.g., Nielson \& Jensen, 1994; Nielson, Radtke, \& Jensen, 1996; Nielson, Yee, \& Erickson, 2005; Revelle \& Loftus, 1992; Walker, 1958), likely because the memory consolidation process is believed to take considerable time-perhaps $30 \mathrm{~min}$, or even hours or days (Revelle \& Loftus, 1992; Torras-Garcia, PortellCortes, Costa-Miserachs, \& Morgado-Bernal, 1997; Walker, 1958).

Studies specifically examining the effects of arousal and emotion on the memory consolidation process in humans are as yet few. Although a number of studies have examined memory modulation via arousal or affective techniques, these have predominantly administered modulatory treatments such as glucose prior to learning or task performance, thereby potentially affecting encoding or

[Neurobiology of Learning and Memory, Vol 84, No. 1 (July 2005): pg. 42-48. DOI. This article is (c) Elsevier and permission has been granted for this version to appear in e-Publications@Marquette. Elsevier does not grant permission for this article to be further copied/distributed or hosted elsewhere without the express permission from Elsevier.] 
consolidation (e.g., Cahill \& McGaugh, 1995; Mohanty \& Flint, 2001). In contrast, a few studies have more directly mirrored rodent studies, administering treatments after learning, during the consolidation interval. Nielson and Jensen (1994) investigated the effects of moderate muscle tension-induced arousal after learning on later memory retrieval in both older and younger adults. The older participants were either healthy and not taking any medications, hypertensives taking a calcium channel blocker or an angiotensinconverting enzyme inhibitor, or hypertensives taking a $\beta$-adrenergic receptor antagonist ("beta-blockers"). The results indicated that the induction of muscle tension shortly after exposure to target words embedded in paragraphs increased heart rate, and enhanced delayed recall and recognition of the words for all participant groups, except those older subjects taking $\beta$-blockers. $\beta$-blockers inhibit physiological response to arousal and emotion. Nielson et al. (1996) used this muscle tension procedure in a within-subject design and demonstrated that arousal induced during the initial consolidation or retrieval intervals after learning enhanced delayed (30 min) retrieval over either non-arousal or arousal during encoding conditions. A more recent study also showed that an emotional arousal source, a video of oral surgery, shown after learning an unrelated word list, significantly enhanced delayed retrieval of the words (Nielson, Yee, \& Erickson, 2002; Nielson et al., 2005). These studies suggest that hormones and neuromodulators play a significant role in memory storage. Enhanced levels of catecholamine stress hormones (e.g., Gold, 1986; McGaugh, 2000; Nielson \& Jensen, 1994) and/or glucose (e.g., Parent, Varnhagen, \& Gold, 1999; Parsons \& Gold, 1992) can specifically affect memory storage processes. Although most arousal occurs during the emotional event, arousal or emotional events occurring shortly after a learning event can also influence memory storage processes (e.g., McGaugh, 2000; Nielson \& J ensen, 1994; Nielson et al., 1996). Indeed it was recently reported that such arousal manipulations are effective even when delayed 30 min after learning (Powless et al., 2003). The studies have thus far focused on physiological or negative arousal stimuli. Another potentially effective technique is the use of reward.

It has long been believed that certain rewards can enhance the learning or retention of a cognitive task, such as when future performance on a maze or Skinner box task is enhanced by giving appetitive rewards to animals upon completion of a run (e.g., Burns, 
Kinney, \& Criddle, 2000). One consequence of this approach, the positive affect generated by the reward, could influence learning or retention in much the same way that arousal and emotion are thought to do so. Indeed, positive affect is also associated with a catecholamine response, in this case likely dopamine that is comparable to the catecholamine release produced during other types of arousal (e.g., Ashby, Isen, \& Turken, 1999; Bozarth, 1991; Phillips, 1984).

A variety of human studies have shown that mild positive affect, such as that associated with everyday experiences or receiving a small gift, experienced prior to a task can improve cognitive performance, such as creative problem solving (e.g., Estrada, Young, \& Isen, 1994; Greene \& Noice, 1988; Isen, Daubman, \& Nowicki, 1987; Isen, Johnson, Mertz, \& Robinson, 1985) and recall of neutral and positive material (e.g., Isen, Shalker, Clark, \& Karp, 1978; Nasby \& Yando, 1982). It can also alter decision-making strategies (Carnevale \& Isen, 1986; Estrada, Isen, \& Young, 1997; Isen \& Geva, 1987; Isen, Nygren, \& Ashby, 1988). Such a reward, given before the task, could alter performance in a number of ways, including by enhancing motivation, attention, learning, mood congruence, etc. (e.g., Ashby et al., 1999; Revelle \& Loftus, 1992; Walker, 1958). An after learning procedure, such as that used in memory modulation studies, has not been employed but would be a better test of whether a reward can alter memory consolidation. If positive arousal sources are effective, the applications of such an approach as a memory enhancement technique would be much more palatable for a variety of contexts than some of the previously used techniques. Thus, the purpose of the present study was to bring these two literatures together by evaluating the effects of a small, non-contingent reward given after learning on delayed memory retrieval. Both an extrinsic reward, such as a small gift, and an intrinsic reward, an experience that is itself rewarding (e.g., praise, Snelders, Dirk, \& Lea, 1996), were investigated. Immediate word retrieval, measured prior to giving the reward, was not expected to differ between groups. However, it was hypothesized that both extrinsically and intrinsically induced positive affect, given shortly after learning, would enhance recall and recognition of words from a list learned a week earlier.

[Neurobiology of Learning and Memory, Vol 84, No. 1 (July 2005): pg. 42-48. DOI. This article is @ Elsevier and permission has been granted for this version to appear in e-Publications@Marquette. Elsevier does not grant permission for this article to be further copied/distributed or hosted elsewhere without the express permission from Elsevier.] 


\section{Method}

\subsection{Participants}

The sample, participants completing both testing sessions, consisted of 108 undergraduates enrolled in Introductory Psychology ( 94 females, 14 males; mean age $=19.14, \mathrm{SD}=1.2$ ), each of whom received course credit for participating. Assignment to experimental groups was quasi-random, determined by the session for which each individual enrolled. Participants who failed to return for the second session ( $n=14,11 \%$; Control $=2$, Intrinsic $=6$, Extrinsic $=5$, and Posted $=1$ ) were excluded from analysis. All procedures were reviewed and approved by the Marquette University IRB.

\subsection{Design and apparatus}

The study design involved one between-subjects independent variable, Reward Condition (four levels) and the retention tests each as dependent variables. The data were analyzed by one-way Analysis of Variance (ANOVA; criterion: $p<.05$ ) with simple planned comparisons between groups for significant ANOVAs (control vs. each experimental group) and Bonferroni post hoc tests, which are corrected for multiplicity of tests, to compare between experimental groups. The study consisted of two 30 min sessions separated by one week. A short demographic questionnaire was given to record gender and age. It also posed six questions regarding reading behaviors, experience with Latin, and personal and parental life motivation factors. These questions were posed principally to lead participants to believe these factors were of central interest to our study. Thirty highly imageable nouns (imagery rating $>6.0$ ) were selected from Paivio, Yuille, and Madigan (1968) and recorded for visual presentation (white on blue background) at $3 \mathrm{~s}$ intervals on videotape and projected on a large screen visible from the entire room. Of these 30 words, 19 have also been standardized for subjective arousal response (Bradley $\&$ Lang, 1999), showing they fell in the low-moderate arousal range with little variability $(M=4.65, S D=0.81$; range $=3.17-6.27$ on a 9point scale). Memory performance was assessed by an immediate free recall test, followed one-week later by an unannounced free recall test and a 140 -item recognition test ( 30 targets, 110 distracters). The

[Neurobiology of Learning and Memory, Vol 84, No. 1 (July 2005): pg. 42-48. DOI. This article is @ Elsevier and permission has been granted for this version to appear in e-Publications@Marquette. Elsevier does not grant permission for this article to be further copied/distributed or hosted elsewhere without the express permission from Elsevier.] 
distracters were matched for imagery ratings to the target words using Paivio et al. (1968). This target: distracter ratio was chosen to add difficulty to the recognition test, to reduce ceiling effects and guessing; this technique has been used previously (Nielson \& Jensen, 1994; Nielson et al., 1996).

\subsubsection{Reward conditions}

Participants were quasi-randomly assigned to one of four reward conditions based upon which study session they attended. The manipulation occurred in the closing monologue at the end of the first session (see Section 2.3). The Control condition involved a closing monologue with no reward: "Thank you all for coming tonight, and we will see you next week at the same time and same place. Please do not discuss anything pertaining to this study until after the second session next week." The Extrinsic condition used the Control monologue followed by an offer of $\$ 1$ as a token of appreciation: “... As you leave, we would also like to give you each $\$ 1$ as a token of our gratitude because you came here tonight." A second extrinsic reward group was used essentially as a control for the surprise element involved in the Extrinsic condition. For this Posted condition group, the sign-up folder for the experiment included and highlighted the fact that participants would receive $\$ 1$ for their attendance. That is, these participants received the $\$ 1$ reward and associated monologue just as the Extrinsic group did, but they were aware it would be given. The Intrinsic condition used a closing monologue with a "praise" component based upon Maslow's Need Hierarchy (1970) prior to the Control dismissal monologue: "We want to let you know that we and the academic community truly recognize you who put forth the extra effort in coming here tonight. By doing something as simple as volunteering for this study, each of you demonstrates tremendous personal qualities of competence and leadership, and those key qualities, for which you can definitely be proud, will help each of you to become very successful in your life..."

[Neurobiology of Learning and Memory, Vol 84, No. 1 (July 2005): pg. 42-48. DOI. This article is @ Elsevier and permission has been granted for this version to appear in e-Publications@Marquette. Elsevier does not grant permission for this article to be further copied/distributed or hosted elsewhere without the express permission from Elsevier.] 
NOT THE PUBLISHED VERSION; this is the author's final, peer-reviewed manuscript. The published version may be accessed by following the link in the citation at the bottom of the page.

\subsection{Procedure}

\subsubsection{First session}

All testing was done in large-group format; four groups were convened, one for each condition with participants assigned to condition solely by which session they selected. Sessions were run back to back in the early evening on the same day except for the Posted group which was run independently later on to prevent sign-up bias (due to posted notice of $\$ 1$ payment). Upon arrival, participants were given an arbitrary participant identification number and the experimenter briefly explained that the study would involve a short questionnaire and learning a word list. All questions were answered and informed consent was obtained. After the questionnaire was distributed and completed, the participants were instructed to watch the word list presentation carefully and try to remember the words. Immediately after the last word was shown, the participants were instructed to write down as many words as possible from the list (immediate recall test). The experimenter then gave the appropriate closing monologue (i.e., reward condition).

\subsubsection{Second session}

Upon return the participants, who were told to expect a session similar to the first one, were instead instructed to write down as many of the words as possible from the previous week's list (delayed recall test). A recognition test was then administered. Prior to debriefing, participants were asked to indicate, at the end of the recognition test, what they thought was the purpose of this study. Participants were then debriefed, thanked, and dismissed.

\section{Results}

The questionnaire and demographic data are shown in Table 1. One-way ANOVA showed no significant differences amongst the groups for these variables (all $p>.05$ ). Notably, none of the participants accurately guessed the purpose of the study at debriefing. Most said they thought the experiment tested a relationship between how much one had read in high school or enjoyed reading and memory.

[Neurobiology of Learning and Memory, Vol 84, No. 1 (July 2005): pg. 42-48. DOI. This article is @ Elsevier and permission has been granted for this version to appear in e-Publications@Marquette. Elsevier does not grant permission for this article to be further copied/distributed or hosted elsewhere without the express permission from Elsevier.] 
Table 1. Demographic and survey data by group (frequencies, mean \pm SEM)

\begin{tabular}{|c|c|c|c|c|}
\hline & Control & Intrinsic & Extrinsic & Postec \\
\hline \multicolumn{5}{|l|}{ Gender } \\
\hline $\mathrm{F}$ & 24 & 24 & 29 & 17 \\
\hline$M$ & 4 & 7 & 1 & 2 \\
\hline Age & $19.14(.18)$ & $19.17(.24)$ & $19.23(.22)$ & $18.95(.28)$ \\
\hline \multicolumn{5}{|l|}{ Studied Latina } \\
\hline Yes & 4 & 1 & 6 & 1 \\
\hline No & 24 & 30 & 24 & 18 \\
\hline \multicolumn{5}{|l|}{ Enjoy readinga } \\
\hline 1 low, 5 high & $3.57(.21)$ & $3.28(.18)$ & $3.43(.22)$ & $3.89(.24)$ \\
\hline \multicolumn{5}{|c|}{ Books read in $\mathrm{HS}^{\mathrm{a}}$} \\
\hline $1-5$ & 12 & 7 & 15 & 7 \\
\hline $5-10$ & 12 & 13 & 9 & 9 \\
\hline $10-15$ & 2 & 5 & 5 & 3 \\
\hline$>15$ & 2 & 3 & 1 & 0 \\
\hline \multicolumn{5}{|c|}{ Books last yeara } \\
\hline $1-5$ & 18 & 24 & 25 & 12 \\
\hline $5-10$ & 9 & 2 & 5 & 4 \\
\hline $10-15$ & 0 & 1 & 0 & 2 \\
\hline$>15$ & 1 & 2 & 0 & 1 \\
\hline \multicolumn{5}{|c|}{ Guessed hypothesis } \\
\hline $\mathrm{Y}$ & 0 & 0 & 0 & 0 \\
\hline $\mathrm{N}$ & 28 & 31 & 30 & 19 \\
\hline
\end{tabular}

a Two participants in the Intrinsic group did not respond.

\subsection{Immediate recall}

A one-way ANOVA showed no significant difference among the four groups' scores for immediate recall, prior to the experimental manipulation $(F(3,104)=0.27, p \geqslant .84)$. These results are shown in Fig. 1. 


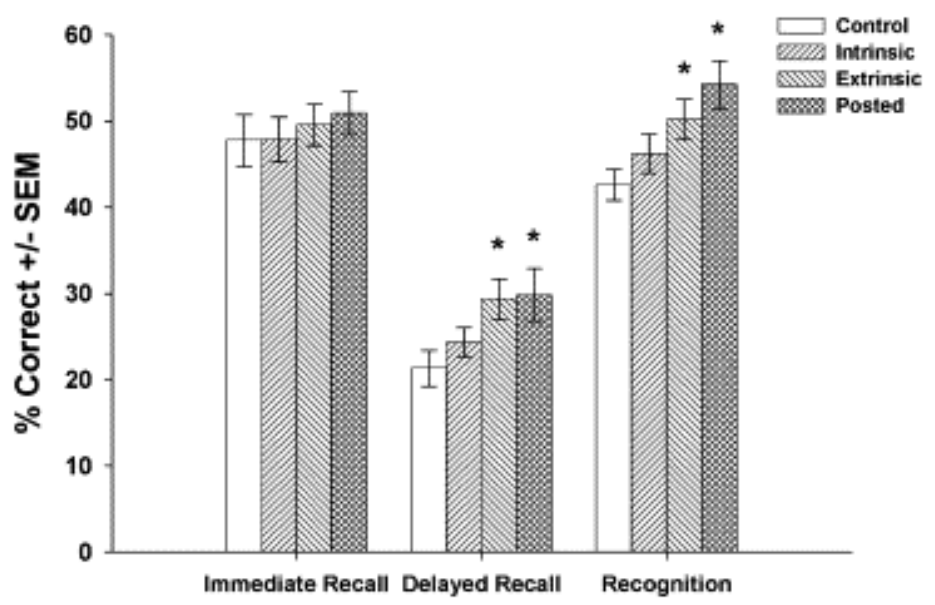

Fig. 1. Memory performance (mean \pm SEM) for each experimental group on each of the three retention tests. There was no significant difference between groups at immediate recall, before the reward manipulation. However, at both delayed retention tests, groups given the $\$ 1$ reward after learning, whether unexpectedly (Extrinsic) or expectedly (Posted), performed significantly better than controls. Intrinsic (i.e., praise) participants were not significantly better than Controls. ${ }^{*} p<.05$.

\subsection{Delayed recall}

The ANOVA of the one week delayed recall test was significant $(F(3,104)=3.22, p \leqslant .026)$. Planned comparisons showed significant differences between the Control participants and those in the Extrinsic $\left(M_{\text {diff }}=8.0, p \leqslant .01\right)$ and Posted groups $\left(M_{\text {diff }}=3.5, p \leqslant .016\right)$. Control participants did not differ significantly from Intrinsic participants $\left(M_{\text {diff }}=2.99, p \geqslant .3\right)$. Bonferroni post hoc tests showed no significant differences between Extrinsic and Intrinsic ( $M_{\text {diff }}=5.0, p \geqslant .6$ ), Extrinsic and Posted ( $M_{\text {diff }}=-.49, p \geqslant .9$ ), or Intrinsic and Posted participants $\left(M_{\text {diff }}=-5.5, p \geqslant .6\right)$. These results are shown in Fig. 1 .

\subsection{Recognition test}

One-week delayed recognition test scores were corrected for guessing using the following procedure: Corrected Recognition $(C R)=(1-E R) \times(\%$ Hits $)$, where $\%$ Hits $=(($ Hits $/ 30$ Targets $) \times 100)$ and Error Rate $(E R)=$ proportion of false alarms (FA/110 Distracters). Analysis is shown for all three indices, \% Hits, ER, and CR, although concentrated upon corrected performance. One-way ANOVA for \% Hits was significant $(F(3,104)=3.7, p \leqslant .015)$, not significant for $E R$ $(F(3,104)=1.1, p>.36)$, and significant for $\operatorname{CR}(F(3,104)=4.31$, 
$\mathrm{p} \leqslant .007)$. Planned comparisons for $\mathrm{CR}$ indicated significant differences between the Control participants and those in the Extrinsic ( $M_{\text {diff }}=7.6$, $\mathrm{p} \leqslant .016$ ) and Posted groups ( $\left.\mathrm{M}_{\text {diff }}=11.7, \mathrm{p} \leqslant .001\right)$. Control participants did not differ significantly from Intrinsic participants $\left(M_{\text {diff }}=3.6, p \geqslant .2\right)$. Bonferroni post hoc tests showed no significant differences between Extrinsic and Intrinsic ( $M_{\text {diff }}=4.0, p \geqslant .9$ ), Extrinsic and Posted ( $\left.M_{\text {diff }}=-4.1, p \geqslant .9\right)$, or Intrinsic and Posted participants $\left(M_{\text {diff }}=-8.0, p=.15\right)$. These results are shown in Fig. 1 .

\section{Discussion}

The purpose of the present study was to investigate the effects of a reward given after learning on delayed memory for a word list. I mmediate recall, prior to the manipulation, did not differ between groups. However, an extrinsic reward (\$1) significantly enhanced word retrieval when tested a week later, even when participants had foreknowledge that they would receive the reward. An intrinsic reward, in the form of praise, produced no significant effect on memory, although performance was somewhat better than for control participants. None of the experimental conditions significantly affected error rate.

In previous studies, positive affect induced prior to a task had enhancing effects on certain types of behavior, including creative problem solving (Estrada et al., 1994; Greene \& Noice, 1988; Isen et al., 1985, 1987), recall of neutral and positive material (Isen et al., 1978; Nasby \& Yando, 1982), and decision-making strategies (Carnevale \& Isen, 1986; Estrada et al., 1997; Isen \& Geva, 1987; I sen et al., 1988). Furthermore, physiological or negatively valenced arousal states induced shortly after a task have been shown to enhance memory for semantically unrelated neutral material (Nielson \& Jensen, 1994; Nielson et al., 1996, 2002; Powless et al., 2003). Positive affect conditions had not previously been used in a postlearning technique, so the effects of positive affect on memory consolidation had not been previously evaluated. The present findings are consistent with both literatures and indicate that a small reward may affect a number of facets of cognitive functioning, including memory consolidation. Interestingly, one recent study reported that glucose administered prior to a face recognition task did not enhance

[Neurobiology of Learning and Memory, Vol 84, No. 1 (July 2005): pg. 42-48. DOI. This article is @ Elsevier and permission has been granted for this version to appear in e-Publications@Marquette. Elsevier does not grant permission for this article to be further copied/distributed or hosted elsewhere without the express permission from Elsevier.] 
hit rate but rather reduced participant error rate (Metzger, 2000). The reward in the current study alternatively enhanced hit rate rather than error rate, but these findings highlight the need to examine memory performance from all perspectives, particularly on recognition tests.

Small rewards likely affect memory consolidation via their effect on catecholaminergic systems. The findings of the present study are consistent with the conclusion drawn from a body of varying studies (McGaugh, 2000) that hormones and neuromodulators play a significant role in memory storage. Enhanced levels of catecholamine stress hormones (e.g., epinephrine, norpinephrine, Gold, 1986; McGaugh, 2000; Nielson \& Jensen, 1994) and/or glucose (Parent et al., 1999; Parsons \& Gold, 1992) can specifically affect memory storage processes. Positive affect is also associated with a catecholamine response. In particular, there is dopamine release during positive affect (Bozarth, 1991; Phillips, 1984) that has been proposed to underlie performance enhancements and learning improvements associated with positive affect (Ashby et al., 1999). Anecdotally speaking, it was clear that the $\$ 1$ bill generated positive affect. By their reactions, participants in the Extrinsic group appeared both surprised, because it was unexpected, and quite pleased with the gift. Importantly, in the Posted group, where the reward was announced in advance, participants still expressed being pleased with the gift when it was given. Thus, the effect can be attributed to a reward or positive affective effect, but not to a surprise effect; the reward need not be unexpected. In addition, because money is not often given in such a context, there was potentially an element of uniqueness or distinctiveness about this experimental situation that could have made the event more important to each person. Alternatively, it is also possible that participants who received $\$ 1$, whether expectedly or unexpectedly, were somehow more motivated to give greater effort on the delayed retrieval tests. It however seems most parsimonious and consistent with other literature that the effect of the reward on memory occurred via a mood or arousal effect on consolidation, when the reward was given. This interpretation warrants direct evaluation in future studies.

The intrinsic reward was designed to induce positive affect and importance, by basing it on Maslow's (1970) "need hierarchy," but there was not a significant effect of it upon memory. Participants did

[Neurobiology of Learning and Memory, Vol 84, No. 1 (July 2005): pg. 42-48. DOI. This article is @ Elsevier and permission has been granted for this version to appear in e-Publications@Marquette. Elsevier does not grant permission for this article to be further copied/distributed or hosted elsewhere without the express permission from Elsevier.] 
not appear as "moved" by this experience as by the $\$ 1$ gift. Further research is clearly needed to evaluate the potential of intrinsic rewards to modulate memory. Moreover, the difference in response to the extrinsic and intrinsic rewards could mean that the intrinsic reward used here was not well designed to produce positive affect. Indeed, aside from the source of the reward, the conditions also differed in whether the reward was tangible. That is, those receiving an intrinsic reward left the session with nothing tangible, while those receiving extrinsic rewards left with a material gift. Follow-up studies are examining this possibility. On the other hand, it could mean that extrinsic rewards produce more affect because they are viewed as more important or valuable. If the latter were true, these findings could have implications for employers, suggesting that verbal praise for a job well done is less valued than financial compensation (cf. Arnst, 2001).

Physiological and subjective measurements of the affective response to these rewards were not used in the present experiment to preserve the disguise over the role of affect or arousal in the experiment. Now that the effect has been established, the addition of these measures in future studies would add very valuable information to understanding the bases of the effect.

Taken together with previous studies, it is clear that physiological or negatively valenced arousal sources (Nielson \& J ensen, 1994; Nielson et al., 1996, 2002, 2005) and positively valenced (Powless et al., 2003) sources of arousal can modulate the memory consolidation process when induced after learning. Importantly, and consistent with other recent after learning paradigms, the arousal source was not semantically related to the material learned, suggesting that the timing and the response to arousal was central to its effect on memory consolidation, rather than the importance or meaningfulness of the arousal itself (Nielson \& Jensen, 1994; Nielson et al., 1996, 2002, 2005; Powless et al., 2003). Moreover, positive affect and arousal sources might be more suitable for use in a variety of contexts than negative sources. Thus, these results have strong implications for future directions in memory intervention research and practice.

[Neurobiology of Learning and Memory, Vol 84, No. 1 (July 2005): pg. 42-48. DOI. This article is @ Elsevier and permission has been granted for this version to appear in e-Publications@Marquette. Elsevier does not grant permission for this article to be further copied/distributed or hosted elsewhere without the express permission from Elsevier.] 
NOT THE PUBLISHED VERSION; this is the author's final, peer-reviewed manuscript. The published version may be accessed by following the link in the citation at the bottom of the page.

\section{Acknowledgments}

The authors gratefully acknowledge the assistance of Maria Provias and Vasilios Bournas, and the comments of Dr. Robert A. Jensen on a preliminary version of this study.

\section{References}

Arnst, 2001

Arnst, C. (2001). Innovations: Money may not buy happiness, but it could buy memories. Business Week, December 3rd, 67

Ashby et al., 1999

F.G. Ashby, A.M. Isen, A.U. Turken. A neuropsychological theory of positive affect and its influence on cognition. Psychological Review, 106 (3) (1999), pp. 529-550

Bozarth, 1991

M.A. Bozarth. The mesolimbic dopamine system as a model reward system. P. Willner, J. Scheol-Kroger (Eds.), The mesolimbic dopamine system: From motivation to action, Wiley, New York (1991), pp. 301330

Bradley and Lang, 1999

Bradley, M. M. \& Lang, P. J. (1999). Affective norms for English words (ANEW): Instruction manual and affective ratings (Technical Report C1). Gainsville, FL: The Center for Research in Psychophysiology, University of Florida

Burns et al., 2000

R.A. Burns, B.A. Kinney, C.R. Criddle. Position cues and reward memories as compatible components of serial learning. Learning and Motivation, 31 (2000), pp. 236-250

Cahill and McGaugh, 1995

L. Cahill, J.L. McGaugh. A novel demonstration of enhanced memory associated with emotional arousal. Consciousness and Cognition, 4 (1995), pp. 410-421

Carnevale and Isen, 1986

P.J.D. Carnevale, A.M. Isen. The influence of positive affect and visual access on the discovery of integrative solutions in bilateral negotiation. Organizational Behavior and Human Decision Processes, 37 (1986), pp. 1-13

Deutsch and Deutsch, 1966

J.A. Deutsch, D. Deutsch. Physiological psychology. Dorsey Press, Homewood, IL (1966)

Estrada et al., 1997

[Neurobiology of Learning and Memory, Vol 84, No. 1 (July 2005): pg. 42-48. DOI. This article is @ Elsevier and permission has been granted for this version to appear in e-Publications@Marquette. Elsevier does not grant permission for this article to be further copied/distributed or hosted elsewhere without the express permission from Elsevier.] 
C.A. Estrada, A.M. Isen, M.J. Young. Positive affect facilitates integration of information and decreases anchoring in reasoning among physicians. Organizational Behavior and Human Decision Processes, 72 (1997), pp. 117-135

Estrada et al., 1994

C.A. Estrada, M. Young, A.M. I sen. Positive affect influences creative problem solving and reported source of practice satisfaction in physicians. Motivation and Emotion, 18 (1994), pp. 285-299

Gold, 1986

P.E. Gold. Glucose modulation of memory storage processing.

Behavioral and Neural Biology, 45 (1986), pp. 342-349

Gold and van Buskirk, 1975

P.E. Gold, R. van Buskirk. Facilitation of time-dependent memory processes with posttrial epinephrine injections. Behavioral Biology, 13 (1975), pp. 145-153

Greene and Noice, 1988

T.R. Greene, H. Noice. Influence of positive affect upon creative thinking and problem solving in children. Psychological Reports, 63 (1988), pp. 895-898

Isen et al., 1987

A.M. Isen, K.A. Daubman, G.P. Nowicki. Positive affect facilitates creative problem solving. J ournal of Personality and Social Psychology, 52 (1987), pp. 1122-1131

Isen and Geva, 1987

A.M. Isen, N. Geva. The influence of positive affect on acceptable level of risk: The person with a large canoe has a large worry.

Organizational Behavior and Human Decision Processes, 39 (1987), pp. 145-154

Isen et al., 1985

A.M. Isen, M.S. Johnson, E. Mertz, G.F. Robinson. The influence of positive affect on the unusualness of word associations. Journal of Personality and Social Psychology, 48 (1985), pp. 1413-1426

Isen et al., 1988

A.M. Isen, T.E. Nygren, F.G. Ashby. The influence of positive affect on subjective utility of gains and losses: It's just not worth the risk. Journal of Personality and Social Psychology, 55 (1988), pp. 710-717 Isen et al., 1978

A.M. Isen, T.E. Shalker, M. Clark, L. Karp. Affect, accessibility of material in memory, and behavior: A cognitive loop? J ournal of Personality and Social Psychology, 36 (1978), pp. 1-12

Maslow, 1970

A.H. Maslow. Motivation and personality (second ed.), Harper and Row, New York (1970)

[Neurobiology of Learning and Memory, Vol 84, No. 1 (July 2005): pg. 42-48. DOI. This article is @ Elsevier and permission has been granted for this version to appear in e-Publications@Marquette. Elsevier does not grant permission for this article to be further copied/distributed or hosted elsewhere without the express permission from Elsevier.] 
NOT THE PUBLISHED VERSION; this is the author's final, peer-reviewed manuscript. The published version may be accessed by following the link in the citation at the bottom of the page.

McGaugh, 1966

J.L. McGaugh. Time-dependent processes in memory storage. Science, 153 (1966), pp. 1351-1358

McGaugh, 2000

J.L. McGaugh. Memory-A century of consolidation. Science, 287 (14 January) (2000), pp. 248-251

McGaugh and Gold, 1989

J.L. McGaugh, P.E. Gold. Hormonal modulation of memory. R.B. Brush, S. Levine (Eds.), Psychoneuroendocrinology, Academic Press, New York (1989), pp. 305-340

Metzger, 2000

M.M. Metzger. Glucose enhancement of a facial recognition task in young adults. Physiology and Behavior, 68 (2000), pp. 549-553

Mohanty and Flint, 2001

A. Mohanty, R.W. Flint J r. Differential effects of glucose on modulation of emotional and nonemotional spatial memory tasks. Cognitive, Affective and Behavioral Neuroscience, 1 (1) (2001), pp. 90-95

Müller and Pilzecker, 1900

G.E. Müller, A. Pilzecker. Experimentelle beitrage zur lehre vom gedachtniss [Experimental contribution in Learning and memory]. Zeitschnft für Psychologie Erganzungsband, 1 (1900), pp. 1-288

Nasby and Yando, 1982

W. Nasby, R. Yando. Selective encoding and retrieval of affectively valent information: Two cognitive consequences of children's mood states. Journal of Personality and Social Psychology, 43 (1982), pp. 1244- 1253

Nielson and J ensen, 1994

K.A. Nielson, R.A. Jensen. Beta-adrenergic receptor antagonist antihypertensive medications impair arousal-induced modulation of working memory in elderly humans. Behavioral and Neural Biology, 62 (1994), pp. 190-200

Nielson et al., 1996

K.A. Nielson, R.C. Radtke, R.A. Jensen. Arousal-induced modulation of memory storage processes in humans. Neurobiology of Learning and Memory, 66 (1996), pp. 133-142

Nielson et al., 2002

Nielson, K. A., Yee, D., \& Erickson, K. I. (2002). Modulation of memory storage processes by post-training emotional arousal from a semantically unrelated source. Paper presented at the Society for Neuroscience, Orlando, FL. Abstract Viewer and Itinerary Planner, Program No. 381.14

Nielson et al., 2005

[Neurobiology of Learning and Memory, Vol 84, No. 1 (July 2005): pg. 42-48. DOI. This article is (C) Elsevier and permission has been granted for this version to appear in e-Publications@Marquette. Elsevier does not grant permission for this article to be further copied/distributed or hosted elsewhere without the express permission from Elsevier. 
NOT THE PUBLISHED VERSION; this is the author's final, peer-reviewed manuscript. The published version may be accessed by following the link in the citation at the bottom of the page.

Nielson, K. A., Yee, D., \& Erickson, K. I. (2005). Memory enhancement by a semantically unrelated emotional arousal source induced after learning, in press

Paivio et al., 1968

A. Paivio, J.C. Yuille, S.A. Madigan. Concreteness, imagery, and meaningfulness values for 925 nouns. Journal of Experimental

Psychology, 76 (Suppl.) (1968), pp. 1-25

Parent et al., 1999

M.B. Parent, C. Varnhagen, P.E. Gold. A memory-enhancing emotionally arousing narrative increases blood glucose levels in human subjects. Psychobiology, 27 (1999), pp. 386-396

Parsons and Gold, 1992

M. Parsons, P.E. Gold. Glucose enhancement of memory in elderly humans: An inverted-U dose-response curve. Neurobiology of Aging, 13 (1992), pp. 401-404

Phillips, 1984

A.G. Phillips. Brain reward circuitry: A case for separate systems. Brain Research Bulletin, 12 (1984), pp. 195-201

Powless et al., 2003

Powless, M., Nielson, K. A., Gunderson, P., Bournas, V., Galloway, J. \& Czech, D. A. (2003). Human memory modulation is effective using comedy and when delayed up to 30 minutes after learning. Paper presented at the Society for Neuroscience, New Orleans, LA. Abstract Viewer and Itinerary Planner, Program No. 129.10

Revelle and Loftus, 1992

W. Revelle, D.A. Loftus. The implications of arousal effects for the study of affect and memory. S. Christianson (Ed.), The handbook of emotion and memory, Lawrence Erlbaum, Hillsdale (1992), pp. 113150

Snelders et al., 1996

H.M. Snelders, J.J. Dirk, S.E.G. Lea. Different kinds of work, different kinds of pay: an examination of the overjustification effect. Journal of Socio-Economics, 25 (4) (1996), pp. 517-536

Squire, 1986

L.R. Squire. Mechanisms of memory. Science, 332 (1986), pp. 16121619

Squire, 1987

L.R. Squire. Memory and brain. Oxford University Press, New York (1987)

Torras-Garcia et al., 1997 M. Torras-Garcia, I. Portell-Cortes, D. Costa-Miserachs, I. MorgadoBernal. Long-term memory modulation by posttraining epinephrine in

[Neurobiology of Learning and Memory, Vol 84, No. 1 (July 2005): pg. 42-48. DOI. This article is @ Elsevier and permission has been granted for this version to appear in e-Publications@Marquette. Elsevier does not grant permission for this article to be further copied/distributed or hosted elsewhere without the express permission from Elsevier.] 
NOT THE PUBLISHED VERSION; this is the author's final, peer-reviewed manuscript. The published version may be accessed by following the link in the citation at the bottom of the page.

rats differential effects depending on the basic learning capacity.

Behavioral Neuroscience, 111 (1997), pp. 301-308

Walker, 1958

E.L. Walker. Action decrement and its relation to learning.

Psychological Review, 65 (1958), pp. 129-142

[Neurobiology of Learning and Memory, Vol 84, No. 1 (July 2005): pg. 42-48. DOI. This article is @ Elsevier and permission has been granted for this version to appear in e-Publications@Marquette. Elsevier does not grant permission for this article to be further copied/distributed or hosted elsewhere without the express permission from Elsevier.] 